\title{
Google, Human Rights, and Moral Compromise
}

\author{
George G. Brenkert
}

\begin{abstract}
International business faces a host of difficult moral conflicts. It is tempting to think that these conflicts can be morally resolved if we gained full knowledge of the situations, were rational enough, and were sufficiently objective. This paper explores the view that there are situations in which people in business must confront the possibility that they must compromise some of their important principles or values in order to protect other ones. One particularly interesting case that captures this kind of situation is that of Google and its operations in China. In this paper, I examine the situation Google faces as part of the larger issue of moral compromise and integrity in business. Though I look at Google, this paper is just as much about the underlying or background views Google faces that are at work in business ethics. In the process, I argue the following: First, the framework Google has used to respond to criticisms of its actions does not successfully or obviously address the important ethical issues it faces. Second, an alternative ethical account can be presented that better addresses these ethical and human rights questions. However, this different framework brings the issue of moral compromise to the fore. This is an approach filled with dangers, particularly since it is widely held that one ought never to compromise one's moral principles. Nevertheless, I wish to propose that there may be a place for moral compromise in business under certain conditions, which I attempt to specify.
\end{abstract}

KEY WORDS: censorship, China, Google, human rights, moral compromise

\section{Introduction}

Over the past several decades, the demands that business act ethically in international settings have markedly increased. These demands have been raised in a variety of contexts, including sweatshops, the environment, transfer pricing, and human rights violations.
It is terribly obvious that these issues raise many moral conflicts. However, it is tempting to think that there is a straightforward moral solution to these issues, if we only gained enough knowledge of the situations, were rational enough, and sufficiently objective. Of course, we may encounter those who are so self-interestedly focused that they cannot see, let alone adopt, a moral solution. However, in principle, all such conflicts have a moral resolution. We need not theoretically encounter situations in which we are faced with violating important moral principles or moral compromise.

I have become less confident with this approach and want to suggest that there are situations in which people in business must confront the possibility that they must compromise some important principles or values in order to protect other ones. In the process, their integrity comes into question. These are not simply back sliders or bad apples. Rather, given their circumstances, they might plausibly argue they could (and should) do nothing else.

One particularly interesting case that captures this kind of situation is that of Google and its operations in China. In this paper, I examine the situation Google faces as part of the larger issue of moral compromise and integrity in business. Though I look at Google, this paper is just as much about the underlying or background views Google encounters that are at work in business ethics.

In the process, I wish to argue the following: First, the framework Google has used to respond to criticisms of its actions does not successfully or obviously address the important ethical issues it faces. Second, an alternative ethical account can be presented that better addresses these ethical questions. However, this different framework brings the issue of moral compromise to the fore. This is an approach filled with dangers, particularly since it is widely held that 
if one compromises moral values, this is a sign of moral turpitude (see Kuflik, 1979). Others, such as Halfon and Rand, have also argued that one ought never to compromise one's moral principles. Nevertheless, I wish to propose that there may be a place for moral compromise under certain conditions.

\section{Google's situation in China}

Though Google occupies a very significant role today in the business world and in the lives of many individuals, it was only founded in 1998. By 2000, Google had a version of its search engine (Google.com) that was available in Chinese, though provided by servers based outside of China. However, by 2002, users of Google within China began to experience problems. At first, they found they could use Google only sporadically, while at other times it was simply not available (Schrage, 2006, p. 1). Shortly later new problems developed. Internet inquiries regarding certain topics sensitive to the Chinese government were not successful. The cause of these problems, Google claimed, was "... in large measure, the extensive filtering performed by China's licensed Internet Service Providers (ISPs)" (Schrage, 2006, p. 4). Accordingly, certain web pages regarding topics such as Tibet, Tiananmen Square, and the Falun Gong that the government viewed as objectionable were simply no longer available. This filtering process also slowed down other searches on Google such that it was no longer competitive with Chinese-operated search engines. The result was that Google quickly lost market share as fewer and fewer people turned to it.

At the same time, the number of Chinese Internet users was steadily climbing. Elliot Schrage, Google Vice President for Global Communications and Public Affairs, reports 105 million Internet users in China as of 2005. He also refers to projections that there will be more than 250 million Chinese Internet users by 2010 (Schrage, 2006, p. 3).

Accordingly, Google was faced with a crucial decision as to whether abandon service to China or develop a new Google search engine (Google.cn) with servers located in China that would submit to government censorship. The stakes were obviously enormous. It decided on the latter course of action.
Its decision to create an Internet search engine in China involved Google researching the terms that were being blocked in China. The Chinese government did not tell Google which terms should be blocked. On the basis of its own research, Google identified a set of terms for which it would filter the Internet. Absent this filtering, Google would not receive, or be able to retain, the government licenses required to operate. It would not be permitted to operate in China.

Google's decision to begin filtering the content of searches undertaken through its search engine raised a significant outcry from groups such as Amnesty International, Reporters without Borders, Human Rights Watch, and others. Google was accused of violating an important human right of the Chinese people, viz., the human right to freedom of expression and information. ${ }^{1}$ It has been said to be “...complicit in the Chinese government's censorship of political and religious information and/or the monitoring of peaceful speech..." ("Race to the Bottom," 2006, p. 6). It has been attacked for compromising its basic values of honesty, responsiveness, trust, and "Don't be evil," all mentioned in Google's "Code of Conduct." And, indeed, Google has itself acknowledged that the self-censorship that its business in China requires "runs counter to Google's most basic values and commitments as a company."2 Still, Schrage maintains that their decision is compatible with the Google mantra of "Don't be evil.",3

Google's actions and responses raise several questions: (a) What should Google have done in this situation? (b) How adequate is Google's defense of its decision? (c) What is the nature and role of moral compromise in such situations?

\section{Human rights and moral complicity}

The question regarding what Google should have done has two different dimensions to it. First, was Google's filtering of the Internet in China justified, when considered simply by itself, i.e., independently of other moral considerations? Second, was Google's filtering of the Internet in China justified, all things considered? Quite often, an answer to the first question is taken as tantamount to an answer to the second question. Though this may suit the purposes 
of some individuals or groups, this is not a correct or plausible response to the situation Google faces. Google must determine what it ought to do having taken into account all the different aspects of the situation it faces. Still, in making this determination, an answer to the first question is crucial.

Accordingly, does Google do anything wrong when we focus simply on its filtering of the Internet in China? Does this, for example, make it complicit in a violation of human rights or other rights? Answering this question involves knowing whether this human right (or any human right) applies to Google.

The argument that Google is wrong to do this filtering is centrally based upon an appeal to the human right of Chinese people to freedom of expression and information (UNUDHR, Article 19; International Covenant on Civil and Political Rights [Article 19]). ${ }^{4}$ A host of scholars has argued that this right is particularly important, not simply a more peripheral one, such as in Article 24 (UNUDHR) (if it is indeed a human right), which requires periodic holidays with pay.

\section{To whom do human rights apply?}

To whom does this right apply? Who has corresponding obligations regarding this right? Clearly this right pertains to governments. This is true for two reasons. First, they are parties to the International Covenant on Civil and Political Rights and they have signed off on the United Nations Universal Declaration of Human Rights. Second, this right is violated when an organization is able to effectively prevent certain information it chooses from reaching individuals, under its authority or power, who might justifiably seek it. Since governments may fulfill these conditions, they have responsibilities corresponding to this right.

Accordingly, this right, possessed by Chinese people, places an obligation on their government not to violate it. I take it that this means that, valid reasons not withstanding, a government, or other official body, has a duty not to suppress or block information that, absent those official actions, individuals could have access to.

What constitutes a valid reason is, of course, subject to significant debate. I will assume that it is justified to filter some content material, e.g., material that might lead to the immediate and direct harm of other people. In short, the right to information is not an absolute right. For example, the U.S. government has taken down Internet access to Iraqi documents regarding how to build an atomic bomb.

However, filtering of materials that reflects poorly on a current government or that criticizes that government is mistakenly applied. Such information should not be censored. Its censorship is only a way to protect those in power from legitimate criticisms of their failures and abuses of power. The justification of such views would have to draw on accounts such as those of J. S. Mill on liberty. I cannot discuss such views here, but will assume that some such justification can be given. It surely is wrong, accordingly, for the Chinese government to engage in such censorship.

\section{Google and the right to freedom of expression and} information

But what about Google? Does Google have a moral responsibility not to violate or infringe on the right to freedom of expression and information? Is Google also a responsible party? Can it violate this right?

There are two important considerations here. First, if the human rights identified by the UN are portrayed as simply charter or treaty based, they would apply only to those parties, i.e., governments that have agreed to the charters or treaties. Further, some of these human rights identified by the UN could only apply to organizations that are capable of arresting people or bestowing on them a nationality. In either of these cases, private organizations such as Google could not be said to be obligated by those rights. Since private organizations cannot arrest people or grant them a nationality, they cannot violate the rights not to be subjected to arbitrary arrest or to be offered a nationality. And since Google and other MNCs have not signed these documents, such rights could not entail obligations that apply to them.

Second, however, inasmuch as these are rights that have been identified as "human," e.g., rights to life, not to be tortured, to freedom of information and expression, etc., they have been held to apply 
not only for governments party to those treaties or charters, but also for other organizations and bodies relevantly related to the rights holders. In this manner, these rights are not simply charter or legal rights. Further, the human right to freedom of expression and to information is plausibly a derivative right from a more basic right. Commentators such as Shue and Bedau (see Donnelly, p. 39) argue that liberty or freedom is one of the basic rights. Such basic (human) rights are held by all individuals and impose duties on individuals and organizations in relevant roles or relationships with those individuals. In short, governments are not the only ones with duties corresponding to some human rights.

What, then, about the right to freedom of information? What conditions would have to be fulfilled for Google to be said to have a duty not to violate this right? Do private organizations such as Google, the New York Times, or CBS, etc. have obligations corresponding to this right? When would they be complicit in the violation of this right?

Some equate the violation of the right to freedom of information with censorship. They also maintain that "there is no such thing as 'private censorship.' It is only when government uses its coercive powers to inhibit speech that censorship occurs" (Bowden, 1999). On this view, Google could not be accused of censorship. Supposedly, it would follow that it is doing nothing wrong if it blocks some websites. I think the situation is more complicated.

\section{Censorship and the right to freedom of information}

Censorship involves several different features. First, censorship occurs when some entity prevents or restricts members of some group from access to information to which they may otherwise have access. Second, the body doing the censoring must have some authority or effective power over those censored. Hence, governments engage in censorship - they have political authority and police power over their populations. The Catholic Church has, at least in the past, imposed censorship on its followers - it had spiritual authority and power over them. A list of prohibited materials was to be found in the Index Librorum Prohibitorum. So too some Imams in Islam impose censorship regarding materials to which their followers should have access.
They claim spiritual authority to do so. However, an invading army in an unjust war might capture another country and impose censorship. It does not have legitimate authority, but it does have effective power. Third, the restriction of materials is either for the benefit of those who no longer have access to the material or for the benefit of those doing the restricting. If, however, materials are restricted simply because the entity doing the restricting is the sole source of the materials but it does not have the capacity to transmit more materials, then it is not engaged in censorship, as it is standardly understood. Censorship is not a function of the incapacity of a particular organization to transmit information to others who might seek it.

The widely agreed upon cases of censorship occur then due to the actions of governments and churches. However, to the extent that the loyal or the faithful, for example, agree to the authority of those organizations, then their censorship does not violate their right to free access to that information.

Now, a business might exercise power over a group of people and seek to restrict information for its own benefit that they would otherwise have access to. For example, a company which virtually runs a town might do so and would be viewed as censoring the information to which its town members had access (Solely, 2002, p. 36). It would have effective power (if not authority) over the town's people, the ability to block information, and would do so to protect itself. As such, some private (nongovernmental) organizations may also censor the information that others receive and it can either be justifiable or not, depending on what and how that material is censored. ${ }^{5}$

There is, however, a second sense of censorship that occurs when a body has the power to restrict the access of other people to certain information and it does so to protect itself or those who might otherwise have received the information, i.e., it fulfills the first and third conditions, but not the second - it does not have authority or effective power over the recipients. Thus, other businesses have been charged with censorship when they use legal suits to prevent others from researching or discussing problems with their products or operations (cf. Solely, 2002). These actions constitute a related form of censorship. Still, in both cases of censorship, people are not able to receive information to which they would otherwise 
have access. When people can be said to have a right to that information, such censorship is wrong, and the business has an obligation not to interfere.

\section{Google and the right to freedom of information}

So does Google exist in a relationship with the Chinese people such that the right to freedom of information imposes a duty on Google not to block or filter information they might seek through Google's search engine?

There certainly are things that Google can do that will affect or impact that right in certain ways, e.g., limiting access to information. To this extent, it fulfills a first essential condition, viz. that it can affect claims made by rights holders. However, we should be clear on what the right to freedom of expression or information requires. It is not a right that private organizations provide people with any and all information they want. This is not even the case with regard to the government. Instead, it is a right that responsible parties not prevent a person from obtaining information to which they would otherwise have access. Accordingly, the right to freedom of information is a negative right that some relevantly situated entity not block access to information. It is not a positive right that such entities provide that information. Thus, it is a right that governments not prevent their own members or other individuals and organizations from providing information (with the exception of certain kinds that may justifiably be circumscribed) to those rights holders. Accordingly, when the Washington Post does not publish certain stories they are not, as such violating their readers' right to information, since their readers don't have a positive right that the Washington Post provide that information.

However, the Internet is different from a newspaper or even a television or radio station. Private newspapers, radio stations, and television stations may provide their own content, which they then transmit, as well as broadcast material from other sources. Search engines such as Google don't provide the web pages themselves, but they do allow people using the Internet to identify those web pages and find sources of information that are otherwise "out there" but difficult to find on one's own.
Now the formulas they use to search the web to provide this information favor some websites over others, viz., those which, according to their formulas, have a greater citation importance (more links point to that page) and hence correspond with people's subjective idea of their importance. As a result, some web pages get pushed to the back of the pile (as it were) and some not even picked up. This is not a case of censorship or violating anyone's right to information.

However, suppose there were a search engine, New Hope, that decided to give precedence only to evangelical websites and drop or block any others; it would then be an evangelical source of information on the web. Its intention is not to protect its users or itself from access to other websites, so much as to provide its users with the websites they support and think most valuable. In this case, New Hope would not be violating any one's right to other information. If it did this surreptitiously, as it were, then it might be faulted for deceptiveness, but not for the limited nature of its offerings.

Similarly, suppose a different search engine, Open Source, that provides searches of the web. It too has its own algorithms that select various web pages, and place some up front. However, this search engine blocks web pages that are critical of its operations and its impact on communities. Further, it does not inform its customers that it is doing this; it even touts its open nature. This search engine we might accuse of hypocrisy. But has it violated a right of its users to those blocked web pages? They can, let us assume, access them through other search engines or by typing the URL addresses into their Internet Service Providers (ISPs). If New Hope hasn't violated anyone's right to freedom of expression, I don't see that Open Source has violated any right those individuals have. Still, I am inclined to say that Open Source is now censoring (in the secondary sense above) the material it provides. Its intention is to prevent some web pages from being distributed for the specific reason of protecting its own interests or those of others. Thus, some search engines today block websites advocating bulimia, the use of "mindaltering substances," etc. Supposedly intended for the benefit or well-being of their audience, these are forms of censorship (albeit in the secondary sense). Still, given multiple sites, this censorship may take place even though a person's right to information is not violated. 
This conclusion is based on the assumption that there are multiple sources of information and that the censorship by Open Source does not prevent people from obtaining the information they seek from other sources. Accordingly, the right to information is a right that one be able to obtain available information (i.e., it is not blocked to one), but not a right that necessarily attaches to particular private organizations. ${ }^{6}$

Now Google can prevent those using its search engine from connecting to certain web pages through its services. However, it cannot prevent a person from using other search engines or Internet Service Providers to seek out those web pages. Google is a service that people may (or may not) use to obtain information. There are other search engines: Yahoo, Altavista, Baidu (in China), etc. It also does not have an obligation to provide access to any and all web pages to those who want them.

This means that if Google, a private organization, does not provide certain websites, it has not violated people's right to that information, even though under some circumstances it could be accused of censoring those web pages if it did so for reasons of protecting its users or for protecting its own interests. Further, the right to freedom of expression would apply to it only if it could effectively prevent people from obtaining information to which they had a right and which, absent that its actions, they would have access. However, this is not, in general, the case with Google.

I have also noted that Google, or similar private organizations, are not the primary party responsible for the right to freedom of expression and information. Private news organizations and search engines do not violate that right if they withhold from their own services certain information. ${ }^{7}$ Hence, the human right to freedom of expression does not directly apply to Google. In order to be accused of violating the right of freedom of expression, Google would have to have authority or effective power over those rights holders or be part of a group which, acting in concert, prevented people from accessing the information they sought.

\section{Complicity and the role of the Chinese government}

Of course, this last claim points us in an important, new direction. The situation of Google in China is complex because we cannot simply consider Google and the Chinese people. We must also consider Google as operating in the social and political context of China and the Chinese government. Google is being required by the Chinese government, as part of its license to operate in China, to filter items from the Internet of which the Chinese government does not approve and which filtering, on the part of the Chinese government, does violate their citizens' right to information. Google has become part of a system-wide attempt to prevent Chinese people from having access to certain information otherwise available through the Internet. Further, its acting in this way is part of an effort by the Chinese government to ensure that all Internet Service Providers and Search Engines do not permit these web pages to become available to people in China searching for them.

Does this filtering of the Internet at the direction of the Chinese government make Google complicit in the abuse of the right to freedom of information? The answer to this simple question is considerably complex. There is a number of different analyses of "complicity."

To begin with, according to a UN document on "Embedding Human Rights in Business Practices,"

a company is complicit in human rights abuses if it authorizes, tolerates, or knowingly ignores human rights abuses committed by an entity associated with it, or if the company knowingly provides practical assistance or encouragement that has a substantial effect on the perpetration of human rights abuse. The participation of the company need not actually cause the abuses. Rather, the company's assistance or encouragement has to be to a degree that, without such participation, the abuses most probably would not have occurred to the same extent or in the same way (UNHCHR, 2004, p. 19).

There are at least two major conditions here for complicity: (a) The Permits condition and (b) the Assistance condition. These are distinct and separate. Each one might be sufficient for complicity. The Permits condition involves a company authorizing, tolerating, or knowingly ignoring human rights abuses committed by an entity associated with it. When the entity associated with a business is a sovereign government, especially of the size of the Chinese government, this condition does not seem 
applicable. Google is in no position to authorize the Chinese government to do anything. It could, of course, tolerate or knowingly ignore Chinese government human rights abuses. However, the significance of this is uncertain, absent the ability to change what the Chinese government is doing. Besides, the question here relates to what Google itself does as a result of what the Chinese government is requiring them to do. Hence, the Permits condition does not seem applicable to Google. It does not render Google complicit.

The Assistance condition requires that what a company does have a substantial effect on the perpetuation of human rights abuses. Clearly, Google is blocking websites and hence is subject to the accusation (being considered here) that it is violating people's human rights. However, the UN document qualifies this Assistance condition by saying that a company's assistance has to be such that without it "the abuses most probably would not have occurred to the same extent or in the same way." Now understood in a non-trivial manner, it is quite likely that with or without Google's participation, the abuses would have remained largely the same in nature and extent. In fact, Google claims that it can provide more and better information, even of some sensitive materials, although all materials passing through Google.cn are filtered. ${ }^{8}$ Hence, the total censorship may actually be lessened. On this understanding, Google is not complicit.

In fact, I think that both of these conditions are of questionable relevance or guidance in determining Google's complicity. Whether Google is complicit depends, I think, on a different account than the one just given.

We have already seen that a first condition of complicity is that there must be something Google can do that will affect or impact the right to information in certain ways. In short, Google must be able to limit or block the web pages that its users receive when they undertake searches. In this manner, Google has a direct relationship with those who use its services. Users of the Internet in China load the Google program and use it to search for information they want. However, as above, Google is not obligated to provide any particular piece of information.

I have already suggested a second condition as well. If an organization acts in concert with other organizations having a direct responsibility regarding a human right and the resulting combined actions violate that human right, then they share the responsibility for the violation of that right. This condition might appear similar to the notion of direct complicity that the UN Global Compact for business has distinguished. On this interpretation, there is (direct) complicity "...when a company knowingly assists a state in violating human rights." "However, the Global Compact suggests that this requires participation in an act that would itself be a violation of human rights. Hence, it gives the example of a "...case where a company assists in the forced relocation of peoples in circumstances related to business activity." ${ }^{10}$ However, Google is not directly complicit in this manner. Their actions of blocking Internet websites need not be, in themselves, violations of people's rights, as would be the forced relocation of people. Instead, I suggest that another category of obedient complicity is more appropriate. This would occur when a business follows laws or regulations of a government to act in ways that support its activities that intentionally and significantly violate people's human rights. ${ }^{11}$ This requires only that a business engage in actions mandated by a state that significantly and knowingly violate human rights - even though similar actions (in this case, filtering) undertaken simply by the business itself would not violate human rights! ${ }^{12}$

\section{Other conditions for complicity?}

Michael Santoro has offered a "Fair Share Theory" by which the responsibilities attached to human rights are allotted among the diversity of potentially responsible actors (Santoro, 1998, 2000). Two of his conditions for an actor to be responsible for a human right might be deemed relevant for determining complicity. First, Santoro proposes that a multinational corporation (MNC) must be able to effectively engage in behavior consistent with human rights duties for those duties to be allocated to it. Hence, when an MNC is involved in the violation of human rights due to government policies, Santoro maintains that this condition requires that an $\mathrm{MNC}$ has the ability to alter the policies of the government. Accordingly, he looks to the potential effectiveness of a business to "...have a substantial influence on 
the policies of the host government" (Santoro, 1998, pp. 37-38). Only if this were the case, could we attribute the responsibility for avoiding violation of that right to the MNC (Santoro, 1998, p. 36; cf. Santoro, 2000, pp. 154-157).

Second, Santoro maintains that an MNC must be able "to withstand losses related to the proposed duty" (Santoro, 1998, p. 36). If it could withstand retaliation by a government, then the duty at stake might be allocated to it. However, if an MNC did not have the capacity to withstand retaliation by the government, it could not be held to the fulfillment of human rights duties.

In both cases, these conditions imply that Google is not responsible and hence not (obediently) complicit with the Chinese government for violating the right to freedom of expression. On the first condition, it does not appear that Google could substantially influence Chinese government policies. It cannot effectively not engage in filtering and yet still do business in China. It could, of course, as it presently does, offer its ordinary Chinese language Google.com (from outside of China), on which web pages in Chinese are "open, unfiltered and available to all Internet users worldwide" (Schrage, 2006, p. 5). However, it could not effectively offer a Google.cn from within China in an unfiltered version. It does not have sufficient influence within China to alter China's policies (Santoro, 1998, p. 38). Accordingly, on Santoro's view, Google cannot be held responsible for these violations. It is not part of its "fair share" allocation of human rights duties.

On the second condition, Santoro argues that "the capacity of a multinational firm to withstand retaliation by the Chinese government is very limited in most cases" (Santoro, 1998, p. 38). Though Google could withstand Chinese government reprisals in the short run (i.e., by withdrawing from China), this would result in the loss of the world's largest market to Google and significantly harm its development in the long run. From such consequences, Santoro appears committed to the view that the duty not to violate the right to information is not applicable to Google. Accordingly, Google does not have a responsibility to refrain from filtering the Internet in China, and hence cannot be complicit with Chinese government actions.

I believe we should reject these two additional conditions. First, if Google does not have a responsibility to avoid violating this right under these two conditions (it is not part of their "fair share"), then the implication would be that Google is not doing anything wrong when it filters the Internet at the behest of the Chinese government. Accordingly, it would be unnecessary for Google to make any adjustments. They should simply filter the Internet and get on with it. No regrets or sense of guilt is appropriate. They have not done anything wrong.

Some counter-evidence is suggested not simply by the outcry of many people and organizations around the world to Google's actions, but also by the fact that this doesn't capture the response the owners and executives of Google have expressed. They express regret and appear to be troubled by the actions they have undertaken. Of course, they may be wrong. Perhaps, rightly viewed, they should give up their sense of regret. On the other hand, it may also be that Santoro's "fair share theory" does not correctly capture Google's responsibilities in this situation. Indeed, on this first condition, it would appear that an MNC might engage in a wide range of harmful acts for which it could claim no responsibility because it lacked the capacity to influence the government's policies. ${ }^{13}$ This is an open door to irresponsibility.

Second, Google is blocking websites at the behest of the Chinese government in a manner that results in Chinese people being unable to have access to websites to which they arguably have a right of access. Were the Chinese government itself to do this blocking, and there be no ISPs or search engines involved, it would be violating the right of freedom of expression of the Chinese people. However, in the present case, given that the filtering is done through ISPs and search engines, Google is cooperating with the Chinese government in accomplishing this same end. China has set the rules and conditions for Google to operate in China, even if some of this is done only very indirectly.

Still, Google has chosen to place itself in this situation. Google agreed to operate by rules that are part of the Chinese government's violation of its citizens' right to freedom of information. Consider a business that chose to operate in South Africa under apartheid and then followed the South African government's apartheid rules. They would have been considered complicit in the violation of the 
human rights of South Africa's blacks. So too, to the extent that it follows the Chinese government rules in blocking websites that violate the rights of expression of its citizens, Google is also complicit in this abuse of human rights.

It is true that Google and other companies must follow the laws of the countries in which they operate. Since China requires filtering, this is what they must do. However, such pressure, even if codified in a law, doesn't answer the moral question: Is this a just or moral law? And does following it violate important international human rights? Governments may set unethical rules that are racist, sexist, or corrupt. If a business follows such rules, it is participating in the unethical practices those rules structure. I have previously concluded above that a case can be made that China has set up rules regarding access to information that are unjustified and that do violate people's right to information. If this is correct, then playing by those rules and engaging in the resulting system is to engage in unethical practices. ${ }^{14}$ Of course, some will argue that they had little choice but to do so. Still, they did explicitly choose to place themselves in this situation. If they engaged in actions that contribute to accomplishing the purposes of the aims of the Chinese government and these aims violate human rights, then they are (obediently) complicit. ${ }^{15}$

\section{Summary and Google's inadequate defense}

The upshot of the preceding argument is, I believe, that Google is (obediently) complicit in violating the human rights to freedom of expression and information of Chinese people. Actions that Google takes do in fact filter out web pages that the Chinese government finds unacceptable, even though the government has not directly identified those items to Google. Further, the web pages filtered out are the ones that raise political questions and legitimacy questions regarding the Chinese government. These kinds of materials are illegitimately blocked from the citizens of any country. It is true that if Google did not take part in this filtering, the results might be closely the same. However, in contrast to the UN document, "Embedding Human Rights in Business Practice," referenced above, this does not mean that Google is not complicit. In point of fact, the importance of this consideration has been misapplied by those discussing complicity (and Google). ${ }^{16}$

Given this analysis, the inadequacy of Google's own defense of its position is worth noting. Google's position has been defended, through its VP Elliott Schrage, as resting on three legs. First, Google seeks to satisfy the interests of its users. Google claims that by operating in China it can provide a more reliable and faster service than any of its competitors. Second, it endeavors to expand access to information to those who want it. Again, by having a presence in China, Google claims that it can offer more and better information through the Internet than any one else operating in China. Finally, it seeks to be responsive to local conditions. The law of the land is such, Google claims, that either it must filter or it cannot operate in China. Google notes that its regular service, Google.com, on which web pages in Chinese may appear, remains "open, unfiltered and available to all Internet users worldwide" (Schrage, 2006, p. 5).

What is striking about Google's defense is its inadequacy. First, it does not respond to accusations of the violation of the human right to freedom of expression and information. In fact, it does not even speak about human rights or other rights. It is a thoroughly consequentialist response.

Second, this response treats all information on the Internet as the same. Consequently, if Google can offer more information even though it filters some topics, then it is justified in proceeding. However, more information about happy picnics on Tiananmen Square is not the same as less total information (however that is measured) but some that includes the Tiananmen Square massacre in 1989. At the least, Google needs some way to respond to the human rights violation charge. It is true that Google is not engaged in a philosophical debate, but many other businesses have undertaken to speak directly to human rights issues and do invoke talk about human rights in explaining and justifying their actions (see Novartis, Shell, and Levi Strauss).

Third, if Google's response is consequentialist and this adequately defends its "Don't be evil" mantra, then it is hard to understand why Schrage has also said that self-censorship is counter to its basic values and commitments. The only thing that would be counter to those values is providing less information. Any system will involve some restricting or censoring 
some materials. However, not all such information comes under the notion of freedom of expression and information.

Finally, if Google's consequentialist justification were truly successful, then it would seem peculiar that it would have any reservations about its actions. It should simply continue on its present course secure in the knowledge of the resulting good consequences. And yet Google's founders have expressed concern about Google's position. Sergey Brin (one of Google's two co-founders) has spoken of their compromising their values (see Parr, 2006, p. 86). I think this is suggestive of the type of problems that answers that are wholly consequentialist or utilitarian have. They transform various features of the moral landscape simply into their results, rather than entertaining the intrinsic aspects of those features that may be trampled by focusing on their consequences. ${ }^{17}$

\section{Moral compromise}

If Google's filtering the web in China infringes on the human right to freedom of information, then doesn't it follow that Google should stop filtering, and, as a consequence, no longer operate in China? Some move seamlessly from the wrongness of such filtering to the wrongness of Google engaging in filtering all things considered. There is much to be said for this view. However, at this point, we have only considered the wrongness of such filtering. Instead, we need a judgment regarding whether Google should, all things considered, filter the Internet. By this, I mean a judgment that is based upon all relevant moral and non-moral considerations. ${ }^{18}$ If it is wrong for Google to filter the Internet, all things considered, then it should withdraw from China. This may take moral courage. However, anything else would be morally intolerable.

In this section, I wish to look more broadly at the full moral and practical dimensions of Google's situation. Google has multiple responsibilities to various stakeholders. The fact that they may be morally obligated to respond in one way with regard to the rights of some stakeholders does not imply that they must therefore honor that right above all others. Google does not have the luxury of deciding what to do based simply on the basis of this or that right. Instead, they must reach an "all things considered judgment."

In this situation, I believe that a reasonable case can be made that they may be morally permitted, under the present circumstances and subject to certain conditions, to filter the Internet in China. In doing so, they will have indeed morally compromised their values and infringed on the human right to freedom of expression and information. However, all things considered, this is the best decision they can make, even if it is not the most desirable situation one might imagine. ${ }^{19}$ Should these conditions change, they would no longer be permitted to engage in such filtering and must cease doing so, even if it means withdrawing from China.

Two senses of "compromise"

The sense in which I speak of compromise here needs brief, initial attention. Frequently, when people talk about (moral) compromise, they refer to the compromises that occur between two negotiators or two parties who are disputing over some topic or business deal. If each gives up something or some part of what they are seeking, then they can be said to have compromised. Hence, if I want to sell my car for $\$ 20 \mathrm{k}$ and you want to buy it for $\$ 15 \mathrm{k}$, and we agree on $\$ 18 \mathrm{k}$ we have each compromised. This is a non-moral compromise. Moral values or principles are not obviously at stake.

However, people may engage in negotiations and discussions regarding important moral issues, which may also result in moral compromises. Martin Benjamin gives the example of the Warnock Committee on human fertilization and embryology (Benjamin, 1990, pp. 38-40). Some of its members opposed, while some favored, experimentation on human embryos. In the end, the members of this commission found a compromise whereby they could recommend limited experimentation on human embryos (Benjamin, 1990, pp. 38-39). Sher has discussed moral compromises that might occur between abortion opponents and those who defend the right to abortion (Sher, 1981). This form of compromise has been referred to as "the politics of compromise" (Kuflik, 1979, p. 43) inasmuch as two or more parties are always involved. ${ }^{20}$ 
Whether there has been a compromise in this sense with regard to Google in China is uncertain. Certainly, Google is filtering the Internet. It does not appear that China has compromised regarding filtering. However, since we don't know all the terms Google filters, this cannot be determined. It could be (though I suspect it is unlikely) that the Chinese government has permitted Google not to filter some terms that it would otherwise want them to filter. In addition, since Google is now informing Internet users when they filter, and the government has not intervened to prevent this, this might also be a compromise that the Government has made. Certainly, these are not compromises that the Chinese government and Google have openly arrived at. They may not have even arrived at it through negotiation. People may reach compromises without explicitly talking about them or negotiating to arrive at them. So too may businesses and governments. They may reach an "implicit understanding" with those with whom they are dealing. This understanding may embody a compromise. There is uncertainty here not only for outsiders who view Google, but there may also be considerable uncertainty within Google as to what the Chinese government will or will not do. The government does not tell them exactly what they must filter. In a psychologically clever move, the Chinese government leaves it up to Google to make a decision as to which items it will filter. Such uncertainty, it has been said, leads to greater levels of self-censorship. ${ }^{21}$

I wish to speak of compromise in a different sense of "moral compromise." This is the compromise when one does not live by or fulfill one or more (of one's) moral principles or values, but instead does something that violates them in order to fulfill other values and principles one also holds to be important that cannot be fulfilled if the first values or principles are fulfilled. These compromise situations arise when one cannot fulfill all the values or principles upon which one operates. In such situations, either one or the other of the values or principles one subscribes to will be violated by what one does.

This is the sense of "compromise," I believe that the leaders of Google have used and applied to themselves. Sergey Brin is quoted as having said "And we decided in the end that we should make this compromise" (Parr, 2006, p. 86).

\section{Two objections}

There are two objections to the direction the preceding argument has laid out.

First, it might be objected that this view involving compromising on matters of principles such as human rights is not really of ethical interest, but is, instead, simply a form of moral dissolution. For example, Benditt comments that "we expect people to stand for something, and we think less of a person who is not willing to espouse any principles, and even worse of one who vacillates, particularly when it appears that the principles he espouses serve his own interests. So to compromise on matters of principle is to risk a loss of esteem, not only on the part of others, but also on one's own part" (Benditt, 1979, p. 31). Similarly, Halfon and Rand are among those who argue that people (and businesses) ought never to compromise their moral principles (Halfon, 1989; Rand, 1964). ${ }^{22}$ Kuflik notes that some believe that "the willingness to compromise is a sad but sure sign of moral turpitude" (Kuflik, 1979, p. 38). Accordingly, the argument that Google may be permitted to filter the Internet, and thereby engage in this form of moral compromise, faces significant opposition. $^{23}$

Nevertheless, I think the notion of moral compromise does have ethical interest and is not simply a question of moral dissolution. All our values do not necessarily align in all circumstances. To protect one (set of) values, one may have to sacrifice others. This situation may not arise for utilitarians. Whether it does or not I cannot discuss here. But if it does not, I believe it is a shortcoming of utilitarianism that it does not capture this aspect of human moral experience. In the cases I have in mind, one makes difficult decisions that leave one with a sense of violation and loss, and possibly of guilt, because of the moral residues that remain, while one does what one thinks one must (all things considered) do.

Second, it may be objected that if our rights and principles are properly described or specified, they will take account of possible exceptions to them. Accordingly, we are not violating a particular rule or principle when we act according to that exception. A standard example, often offered, is that of the "No Parking" sign, which allows for parking between 9 $\mathrm{pm}$ and $7 \mathrm{am}$. If a car parks there over night, it has not violated the "No Parking" rule. Tom 
Donaldson defends this kind of view in his "Compatibility Proviso," which holds that "so long as a right satisfies... [a fairness-affordability conditions he specifies] honoring it is compatible with honoring all other fundamental international rights" (1989, p. 77). Another form of this approach to morality is identified by Martin Benjamin who speaks of the "Doctrine of Moral Harmony," which holds that through "additional knowledge and further reflection" we can ultimately "...devise a consistent and comprehensive theory that will be capable, at least in principle, of resolving all moral conflicts without remainder" (Benjamin, 1990, p. 82).

On the contrary, I suggest that rights are based upon important interests that people have (see Raz). Neither those interests nor their rights are absolute. Let us suppose that those interests (and rights) have been properly specified. The interest in information and the right to it does not extend to extreme forms of violent pornography, or how to build nuclear terrorist weapons, etc. That is, preventing people from obtaining that information is not opposed to their interests and does not violate their rights. Focusing then on justified interests and properly specified rights, it is still the case that any particular set of rights (interests) is not the only one that exists for those individuals. They may have multiple rights and interests. Absent some principles of the harmony of moral rights, duties, and interests, it is possible that these rights may conflict. ${ }^{24}$

Donaldson defends his compatibility proviso on the basis that "in the long term...neither welfare nor traditional rights need be sacrificed on the basis of the other" (Donaldson, 1989, p. 80). In short, it is not necessary to sacrifice traditional rights of justice to provide for welfare rights involving bread and housing. The underlying reason is that "a proper system designed to protect justice is remarkably inexpensive; indeed, it probably has a negative cost" (Donaldson, 1989, p. 79). However, this is not persuasive. First, it depends on various factual assumptions regarding the costs of administrative systems for justice and welfare. Surely, they might conflict, even in the long run, depending on what those systems involved. And, second, the issue here is not simply about the contrast between welfare and justice, but whether, as others have also contended, various rights may conflict, even after they have been specified. Thus, Hampshire, Berlin, Williams, and Benjamin have held views that Berlin has expressed in the words that "the belief that some single formula can in principle be found whereby all the diverse ends of men can be harmoniously realized is demonstrably false. If, as I believe, the ends of men are many, and not all of them are in principle compatible with each other, then the possibility of conflict - and of tragedy - can never wholly be eliminated from human life, either personal or social" (Berlin, 1958, p. 169). ${ }^{25}$

Accordingly, the present objection to the conflict of rights would have to maintain that there is some over-riding principle (or right) that subordinates other principles and rights in a particular situation since any actions that otherwise would be contrary to it are written into the nature of that right. I suggest that this is a form of gerrymandering of rights to suit the purposes of those who seek to avoid moral conflict and moral residues. Much simpler is merely to say that those rights conflict and one may have to decide that, all things considered, one of the rights must be overridden, in the sense that it must be violated or infringed upon.

\section{Ways moral compromises may arise}

On this view, cases of moral conflict and compromise may arise in a variety of ways. Sometimes, they involve compromising moral values for other moral values. Perhaps the Prime Minister of a country with a parliamentary system commutes the sentence of an individual who has committed a crime, because one of his major supporters (who leads another party) threatens to withdraw his support unless he does so. Without that support, the government would have collapsed. No other coalition of parties is able to run the country. And with the collapse of the present government, the different factions in society will succumb to violent actions against each other and further chaos through this society will ensue. By granting the commutation, the leader has compromised, even though it may be for good reasons.

One of the classic examples of moral compromise between moral values is one Sartre describes of the son who is torn between staying home to help his mother during World War II or leaving her to join the French forces. Here, as in other cases, we find conflicting values that cannot be rendered 
compatible. One of them will have to be given up. If the son joins the French forces, he will feel that he has done less than a son should do. He will have failed his mother. And if he stays with his mother, he will have failed as a patriot and defender of his country. One way or the other, the son will be compromising one of these crucial values.

However, moral compromise may also arise when self-interest is involved. Suppose that an elected official who opposes crime and corruption is up for re-election. However, to get reelected, he is faced with striking a deal with a crime boss to go easy on one of his associates in exchange for help in getting reelected (see Halfon, 1989, p. 103f). For the elected official to go easy on the associate of the crime boss simply to stay in office would be such an example (whether or not he is justified in doing so).

It should not be thought that the compromise of self-interest to fulfill one's moral responsibilities to others is a matter for little moral consideration. A wife might give up having a career, something we would ordinarily attribute to her self-interest, in order to care for her children (and husband). She might feel that she has made large compromises in her life. She might even be angered by them and harbor some resentment. Still, she thinks it is what she ought to have done, all things considered. She does, after all, have multiple interests, among which are having a husband and children. And though there may be an admirable moral dimension to her actions, she has also importantly sacrificed herself in ways one might think that exceed what morality should demand.

\section{Conditions giving rise to moral compromise}

The preceding examples embody a particular set of circumstances that is attached to the instances in which we believe that moral compromises might be called for or permitted. That is, it would be mistaken to treat any failure to act in accord with one's moral principles and values as a case of (justified) moral compromise. If I go into a store and steal a tie, simply because I don't want to pay for the tie, I have engaged in theft. Someone might say that I have compromised my values, assuming that they included private property. But here "compromised" simply means "broken" or "violated." Benjamin might call this a form of compromise as betrayal
(Benjamin, 1990, pp. 8-10). This is not the sense of compromise at stake here.

Instead, as I note above, I mean this term in the different sense that in order to realize certain justifiable values, you must violate other (justifiable) values which you also hold and whose realization cannot be made practically compatible with the first set of values. Typically, these are conflicts between moral values or principles. However, as the above examples suggest, sometimes they may be between moral values or principles and terribly significant life projects a person might be involved in. ${ }^{26}$

It is important, then, to identify the circumstances in which such conflicts arise that may call for moral compromise. I believe that they include the following features: (a) factual uncertainty; (b) nondeferrable decisions; (c) moral complexity; and (d) vulnerability. ${ }^{27}$

First, there are factual uncertainties surrounding situations involving moral compromise. We may not know what are the consequences or implications of adopting one or another course of action. If the leader of a country does not give in to the blackmail of a prominent supporter, will the country really descend into chaos? If he does give in, will his future credibility be undercut such that he cannot effectively lead?

In the case of Google's decision whether to move into China or remain outside, it faces a number of uncertainties. As already noted, the Chinese government does not tell it which terms to filter, but it is clear it must filter. Thus, Google must engage in self-censorship without any clear guidelines. It does not know for sure which terms must be or need not be filtered. Similarly, Google does not know what the future portends for continuing or relaxing censorship in China. China has opened up considerably in recent decades. What might the future hold? The support of the Chinese people for different forms of censorship is also uncertain. Finally, the effects of remaining outside China involve their own uncertainties. Possibly, Google could survive without being in China. However, by largely giving up what will shortly be the largest Internet audience in the world, it is reasonable to conclude that Google will place itself at a considerable competitive disadvantage in this market. This will have spill over effects in other markets. In any case, it knows that other competitors are actively engaged in the Chinese 
Internet market. Google would be one of the only companies to remain outside of China. Still, the results of filtering - or not filtering - involve many factual uncertainties.

The circumstances of moral compromise also involve situations in which a decision is nondeferrable. If one's decision could be put off until one was more certain regarding the outcomes or implications of one's action, one might not have to compromise. Instead, in situations of moral compromise, one must decide and cannot defer that decision until things are more clear or the conflicts have possibly dissolved.

In the present case, Google also faces a decision that is nondeferrable. Its Chinese major competitor (Baidu) expanded from 2.5\% of the market in 2003 to $46 \%$ of the market in 2005. Google had fallen under 30\% (and was continuing to fall) (Schrage, 2006 , p. 4). There is no reason to think that this situation would not continue to deteriorate. In 2002, 4 years before Google's decision to enter China, the first disruptions of their search engine began. Google waited for approximately 3 years. It is plausible to think that a decision could no longer be deferred.

There is, then, a certain unavoidability to Google's situation. It cannot avoid the requirement to block websites if it operates in China. And if it does not operate in China, it cannot avoid the detrimental consequences of not blocking. Either way it operates, blocking or not-blocking, it will be faced with dramatic consequences and implications. It could try to reduce the effects of blocking (see below); however, reducing the effects of not being in China is much more difficult!

Situations involving moral compromise are morally complex. Only because there are multiple and conflicting principles and values, which cannot practically be made compatible, does the question of compromise arise. ${ }^{28}$ There are, then, two dimensions to such moral complexity, an action and a normative dimension (see Jeurissen). The action dimension involves greater complexity the more a moral agent faces "heterogeneous forms of action," which cannot be made compatible. And the complexity of the normative dimension increases the greater the divergence and multiplicity of the normative views and frameworks (see Jeurissen, p. 16).

Google faces such a morally complex situation in this case. It faces multiple, conflicting, and incompatible responsibilities, which it cannot fulfill at the same time without violating or infringing on some of them. As I noted above, what Google requires is an "all things considered" judgment. What it should do does not simply follow from the fact that it is violating this particular human right. Garrett Hardin has offered as the first law of Ecology that "You can not do only one thing." This applies to most of life and it applies also in the case of Google. Indeed, if there were only one responsibility, principle or value at stake, the need of compromise would be less likely. Instead, the question of compromise arises in situations involving multiple values and principles.

Accordingly, opponents of Google's actions, e.g., Amnesty International or Reporters Without Borders, tend to focus just on the one thing they are concerned about, viz., Google's filtering of the Internet and the human right involved. Hence, they conclude, quite plausibly as I have argued above, that Google is infringing on this right and should not filter the Internet. However, this means that they do not see Google's situation in its full context, and the "all things considered" decision it must make.

Instead, Google has multiple responsibilities that must be taken into account. These may be dismissed by some, but to Google they are very important. For example, Google is a business within a business/ market system in which what it can do is conditioned by what others do. Its continued existence depends on how well it fares with regard to its competitors. Too often, business ethicists fail to take into account this competitive context. What they end up doing is something like giving advice to a football player or a boxer, without considering that they are playing football or boxing. Surely such advice to people in those roles would not be of much help.

Within this competitive system, Google has a responsibility to try to maintain its business if not to continue to develop it as a sustainable enterprise. ${ }^{29}$ This responsibility falls within the demands of economics, the law, and morality. Accordingly, Google must seek to determine what are the economic, moral, and legal rules of the competitive marketplace they face. These are dynamic, not static. Thus, Google has responsibilities to follow the laws of the countries in which it operates. This is not an insubstantial point, though not finally determinative if the laws are (substantially) unethical. Still, the guidance of law cannot simply be swept away either. 
Google must consider how its actions take place within those legal rules, as well as what to do when others break the rules, or the national law officers are not properly officiating. It is relevant, then, if others such as Microsoft, Yahoo, Cisco, not to mention Chinese Internet companies like Baidu do not refrain from filtering, but operate under the restrictions that require filtering of the Internet. This is not to maintain that if everyone else is filtering, then Google is permitted to filter. However, it is to say that it is morally relevant consideration for Google to take into account in determining the moral complexity of the situation it faces and how it will impact adherence to this human right in China as well as the future of Google.

Other responsibilities and relevant factors Google must consider involve the sources of their capital. Since some of their capital comes from stockholders who have invested expecting a profitable investment, they also have responsibilities to their stockholders. ${ }^{30}$ The point here is not simply that this will increase the wealth of the stockholders, at least in the short term. There are news accounts that Google does not expect any return on their investment in China for some time. One of Google's founders, Sergey Brin, is reported to have said that "he thought it would be years before Google would make much if any profit in China. In fact, he argued, going into China 'wasn't as much a business decision as a decision about getting people information"" (Parr, 2006, p. 86). One can imagine that in a competitive world, there is importance also simply to winning the race, i.e., to making the best or most dominant product (and obviously these are not all the same). There is pride and honor at stake. These are also powerful motivators. Nevertheless, Google does have fiduciary responsibilities to stockholders not to diminish the value of their stock. Whether or not Google's operations in China are now profitable, without direct access to potentially 250 million Chinese Internet users (in the next 5 years), Google could jeopardize the investment of its stockholders.

Google has responsibilities to other stakeholders as well, e.g., to employees. Some of these responsibilities are to continue to develop the business, which will involve protecting and developing jobs and employment possibilities. They may also include acting in accordance with its proclaimed values, e.g., "Don't be evil"! Some of these responsibilities to its employees are to those in China. If Google were not to filter the Internet, it would put its Chinese employees at risk of fines, harassment, or imprisonment. There are news reports of Chinese police berating officials at Chinese portal companies, as well as fining and imprisoning those who violate censorship laws. Beyond these threats, those employees might simply be out of a job if Google's search engine defined Chinese censorship laws.

In addition, Google views its mission as providing information as fast as possible to its users. It has argued that even if they filter the Internet according to government wishes, they can still provide information that Chinese are not otherwise obtaining: “Google could still improve Chinese citizens' ability to learn about AIDS, environmental problems, avian flu, world markets" (Parr, 2006, p. 86).

Finally, Google may also be seen as an important life project by Page and Brin, not to mention many others at Google, to make the best, most notable Internet server and not be handicapped by restrictions that others are not accepting. Some ethicists, e.g., Bernard Williams, have emphasized the importance of such life projects in ethical determinations.

The fourth feature of the circumstances of compromise is that of vulnerability. If a person or organization was not vulnerable to others when it did, or did not, follow moral (and other) rules and principles, the question of compromising would not arise. Only because they may suffer the impact of following (or not following) certain rules and principles, does the question arise as to whether they should not do so, and hence compromise on one (or more) of these.

In the present instance, Google is vulnerable in several different ways to being harmed by actions of the Chinese government and its competitors. Google could refuse to enter the Chinese market. But this, I am supposing, would have significant negative implications for its use in China. It would slowly decline to the role of a very minor player. We might further suppose that this would negatively impact Google's future. If it did not filter what the Chinese government wanted filtered, its employees might be subject to fines, harassment, or imprisonment. If it tries to protest this filtering to the Chinese government, it is unlikely that the government will change its course. 
In addition, it is important to note that the U.S. government and the European Union have not complained loudly or strongly against China's filtering of the Internet. Neither has withdrawn support from China. It is true that members of the Congress summoned Google, Microsoft, and Yahoo executives to testify before Congress, but other than moral venting, it appears that little has come from these hearings. ${ }^{31}$ The U.S. Congress has not passed its own laws or resolutions to address the issue of censorship in China. It continues to support business with China.

All the preceding renders Google's (moral and non-moral) interests vulnerable to the actions of its competitors and the Chinese government, as well as the inactions of other governments and international bodies. Since there is no effective legal authority to punish violations of the rules, if Google does not violate the relevant human rights, it may likely be the only one. Other violators of these rules will prosper. $^{32}$ This does not, of course, justify its violating a human right. However, it does form part of the vulnerability Google experiences that constitutes part of the conditions of moral compromise they face.

Now, given that Google faces a situation so described, one involving conflicting and incompatible responsibilities, some moral and some prudential, how should Google decide? As I noted above, many have urged that it should be faithful to its mantra, "Don't be evil." It is a question of integrity. It should not violate the human right at stake. In this manner, I suggest they are urging Google to be morally pure and thereby to make a moral point for others - after all, Google is big and powerful.

In response, I want to argue that, within the above circumstances, Google may be justified in engaging in a moral compromise of one of its own principles and thereby violating this human right. This will, however, leave it guilty of a moral violation. This moral compromise is rendered permissible because of the other responsibilities that Google has. This is, in fact, how Brin describes what they did: "We decided in the end that we should make this compromise" (Parr, 2006, p. 86).

What is desirable, I believe, about this argument is that it will leave Google responsible and guilty for having done something wrong and against its own values. This moral violation then gives NGOs and others grounds to complain against Google's actions. It also leaves Google sensitive to their criticisms. They cannot simply be whisked away. On the other hand, though Google may find itself in circumstances that open the door to compromise, it will require some form of justification to go ahead and filter the Internet. How to make this argument?

\section{Criteria for justified moral compromises}

Moral compromise is a dangerous door to open. Once it is opened, unless we are careful, all sorts of morally questionable actors may try to push through. We need some way to limit access to the room that lies behind. We need to know under what conditions some moral compromises, but not others, would be justifiable. ${ }^{33}$

Benjamin argues that actual moral compromise must be a matter of practical knowledge. A decision to seek or accept compromise, he says, will be highly context dependent and turn on insight, imagination, and interpersonal sensitivity and skill. It will turn, too, on complex and often unpredictable interactions of particularly historically situated individuals. As such, the exercise of judgment is not simply a matter of taste. Arguments must be given and defended. Underlying these arguments must be certain values.

In this situation, a moral compromise involves doing something one believes is wrong to do, but this may be morally permissible if it is outweighed by other considerations. What it must be outweighed by need not be some single other principle or value. Instead, it could be (and generally will be) a combination of other values, principles, and morally relevant considerations.

There are several conditions that must be fulfilled for a moral compromise to be justified. ${ }^{34}$ For Google's compromise to be justified, it must take into account the fairness of its actions, the harms those actions will cause, and its own integrity. ${ }^{35}$ To do so, we should look to the four criteria of fairness, harm, integrity, and mitigation.

\section{Fairness}

The question of fairness regarding proposed moral compromise arises in at least two different ways. First, does the moral compromise result in unfairly disadvantaging others who do not violate the rules, 
values, or principles in question? If a moral compromise unfairly disadvantages others who do follow the rules or principles, that compromise raises more significant moral questions and is less readily morally acceptable. Second, do the demands of morality place an unfair or unrealistic burden on a moral agent such that the violation or infringement of some moral principle or rule seems warranted even though the principle or rule is otherwise justified? In such cases, a moral agent may decide to violate that principle and hence engage in a form of compromise.

Consider the first issue of unfairly disadvantaging others who do act in accord with the rule or principle. This situation may arise in any number of ways. One such circumstance that Kavka emphasizes is whether "there is no effective legal authority to punish violations of the rules" (Kavka, 1983, p. 63). Actually, I think the circumstance ought more plausibly to refer to whether there is no legal or moral authority that can effectively punish the violations of the rules. In this situation, an agent who opts to be a free rider by violating a rule that others follow places other moral agents at an unfair disadvantage. Certainly, in the case of Google, the Chinese government will not punish violators of the relevant human right. Further, in this case, all Google's competitors (both national and international) are violating this human right. If Google did not violate this right, it would be the only one. The unfair disadvantage would be imposed on Google, not the other way around. Whether morality does (or can) demand this I consider below. In addition, no major national governments have resisted this filtering. Not even the UN has made a strong statement on this matter. Accordingly, this part of the fairness condition would not seem to require that Google take this path alone.

Second, the fairness condition arises with regard to whether the moral compromise is a response to unreasonable or unfair moral demands on oneself. That is, would the effects on one of not violating some right, value, or principle be so significant or substantial that they reach beyond what morality might reasonably demand of a person (though not, perhaps, what a person capable of supererogatory actions would do). In short, this aspect of the fairness question raises the issue of how much morality can demand. ${ }^{36}$
Crucial to the present fairness condition is the contention that any view of morality that required individuals to act in ways that would significantly harm or destroy them over a substantial period of time is an unsatisfactory view of morality. ${ }^{37}$ Of course, morality may require a person to make sacrifices. In exceptional situations involving great harm to others, it may require, not that a person or a business sacrifice its existence, but that they are prepared to place themselves in a situation in which their existence might be harmed (or sacrificed).

Consider, for example, the situation of whistle blowers faced with some harm or wrong that they are aware of and believe that by their action they can stop or impede. Richard De George has argued that in such cases, a person is permitted, but not required, to blow the whistle if he is aware of some serious harm a business will inflict on others and if that person reports this knowledge to relevant superiors. However, De George maintains that morality only demands that he blow the whistle if he has credible evidence of the likely harm and he has good reasons to believe that by going public the threatened harm will be prevented, i.e., he will be successful (De George, 2006, pp. 308-313). That is, absent a chance of success, De George argues that whistle blowers are not obligated to blow the whistle (De George, 1999).

In short, De George argues that morality does not demand that a person potentially sacrifice himself to reveal a harm that others are (or may be) doing when there is no likelihood of positive gain. Only if the potential whistle blower can stop the potential harm, does the person have that obligation, albeit still at risk to him or herself. Morality, De George has contended, does not demand self-sacrifice when there is little or no likelihood of success.

Similarly, it is this issue, I believe, regarding the demands of morality that can be seen in Santoro's concerns with respect to the capacity of businesses to withstand retaliation against its actions. Santoro contends that an "actor's capacity to withstand losses related to the proposed duty" is a necessary condition in determining whether the duties associated with a particular human right may be fairly attributed to a business (Santoro, 1998, p. 36). Thus, he argues that "the capacity of a multinational firm to withstand retaliation by the Chinese government is very limited in most cases. Even large multinational 
firms in industries such as aerospace, telecommunications, energy, and automobiles must fear losing out to European and Japanese competitors on multibillion dollar joint-venture contracts" (Santoro, 1998, p. 38).

Accordingly, moral compromises must be measured by a fairness criterion, which has two different dimensions - fairness to others and the fairness of moral burdens on oneself. In the latter case, the moral responsibilities of a business or individual do not, ordinarily, call for or demand self-destructive actions. If a moral agent does engage in actions of this nature or actions that are beyond what is ordinarily required, we speak of supererogatory actions, not ones that are ordinarily obligatory. Consequently, assuming that remaining outside China would significantly harm Google as an ongoing organization, which is otherwise fulfilling its responsibilities, it would seem that the moral compromise Google has adopted may be acceptable. There are, however, three additional conditions.

\section{Harm}

Anyone considering a moral compromise must also consider the severity of the violation involved. This takes a number of different forms and measures. First, does the violation or harm threaten the lives or very identities of the people affected by the violation of the rule or principle? If it does, then such a compromise is much harder to justify. In general, the more significant the value or principle one violates, the more important the responsibility to prevent it. Similarly, the more extensive the harm or violation is, the less it can be supported or demanded by other responsibilities one has. If the violation cannot easily be mitigated, the greater is one's responsibility to avoid the act. Likewise, the longer lasting the violation or harm, the more it should be avoided.

In the case of Google, no one's life is directly threatened by its compromise. In fact, Google has taken steps, as we will see, to reduce this possibility. Further, the violation Google is involved in relates only to the Internet, not to other possible sources of information (radio, cell phones, newspapers, etc.). And, as I will note below, there are steps Google can take to mitigate the violation of the right to information.

Second, we might try to determine whether the wrong one does is the sole source of the harm or whether one's actions are "merely" contributory to the wrongs that occur. "Contributory" might be taken in two different senses here. On the one hand, it might be that the action adds additional harms. On the other hand, it might be that the action participates in the harms being imposed, but does not increase their magnitude. It would appear that Google's violations take the latter form, rather than the former. There is, supposedly, no additional information that is denied to Chinese citizens through the actions of Google. Since the government ensures that information if filtered, whether or not Google operates in China, the harm done by Google's own filtering does not increase the harm presently being experienced by people in China. In fact, Google claims that the Chinese are able to get additional information that they are not already getting through their search engine, even though it remains filtered. Thus, Google claims that information about AIDs, various diseases, etc. can be accessed through Google.cn that would not otherwise be available. Google's actions are not like one more truckload of toxins dumped into a body of water. Rather, they are more like another screen or fence that blocks the view of Chinese people no more (and possibly less) than other (government-mandated) screens already in place.

A third guideline is suggested by Kavka who requires as a condition for performing a wrong action that "the interests at stake for the potential violator [must] outweigh...the harm that would be caused to innocent bystanders and compliers." (p. 64). As Kavka puts it, if "innocent third parties would suffer significant harms or disadvantages as a result of defensive violations of moral rules... [it is] considerably more difficult to justify the acts in question" (Kavka, 1983, p. 64). "The moral principle that weighs against defensive violations that harm [innocent bystanders]...is the familiar prohibition against harming the innocent" (Kavka, 1983, p. 64).

In response, I have argued above that the harms that Chinese users of the Internet, the innocent bystanders, sustain are not added to by Google's efforts. Google is not obviously imposing any additional harm on the Chinese people more than they are presently experiencing. Google joins others who are also not providing relevant information to Chinese Internet users. If they did not do business in China, the Chinese people will not have more 
information, and they may have less. Consequently, though they will be complicit in violating a human right and doing so will therefore make them compromise their own values and compromise an important human right, when all things are considered this is a compromise, which does not mean that they are imposing additional significant harms on innocent bystanders.

\section{Integrity}

In making moral compromises, one must also consider the implications for one's own integrity. Halfon argues, for example, that persons (or organizations) of integrity must remain true to their commitments and never compromise their moral commitments. However, he also contends that "this should not be interpreted to mean that a person who is committed to some objective and has integrity must engage in rigid pursuit of some course of action, ideal, or principle. People often reassess their ideals or principles and reevaluate their commitments. What must be avoided by persons of integrity is abandoning their commitments for arbitrary or capricious reasons" (Halfon, 1989, p. 18).

However, one's integrity is not simple; it is complex. The various "parts" will have different implications and result in demands on one that may not always fit smoothly together. At times, one may have to make decisions or choices regarding which values and principles take precedence over others to which one is also committed. If this is undertaken casually or capriciously, one may question one's integrity. However, if it is undertaken with understanding of the moral weight of one's decision and if one does this in some open or transparent manner, then one's integrity may remain intact.

In the case of Google, it must then be solicitous of its integrity. However, it has not acted arbitrarily or capriciously in arriving at the decision to filter the Internet in China. If integrity implies following moral principles and rules, then Google's integrity must necessarily be damaged when it violates a human right. Many of the critics of Google fasten upon this aspect of the situation charging Google with hypocrisy. Google cannot, they say, both maintain its mantra, "Don't be evil" and still maintain its integrity. Strikingly, Google's leaders have said that they think they can.
I believe that Google can be said to have maintained its integrity to the extent that it has done what it thinks best, all things considered, inasmuch as this maximally maintains its core mission. For example, Benjamin speaks of people maintaining their integrity when they accept compromise positions if they are able to protect other important values they adhere to. Hence, "taking into consideration all of their values and principles plus the fact that they disagree and that they are in circumstances of compromise, the compromise solution may be for them more integrity preserving than any available alternative" (Benjamin, 1990, p. 37). He adds that "to choose to preserve as best as possible the overall pattern of one's life cannot be regarded as betraying one's integrity. Indeed, in such circumstances, a compromise may provide the best means to preserving it" (Benjamin, 1990, p. 37).

Accordingly, violating a human right, under the circumstances Google faces, does not mean that wrong is not done. It does mean that Google is not pure. It has compromised. Still, considerations previously offered above support their decision to engage within China. And though its integrity has been sullied, it is mistaken to contend that one's integrity demands purity. Rather, the integrity of those involved in business, political, and social action must be focused on an inner core of values over the long run. Consequently, Google might well better view its mantra, "Do not be evil," more as an ideal, rather than a directive that can never be violated. Only the moral saint may be able to realize this ideal in all his or her activities. However, the integrity of ordinary humans and businesses does not require that they act only at the ideal (or supererogatory) level.

\section{Mitigation}

A final condition regarding moral compromise regards the manner in which one goes about violating a moral demand one faces. When one is confronted with infringing on some right, principle, or value, then moral compromise is defensible only if one also attempts to mitigate that violation. Contrariwise, if a person could reduce the impact or seriousness of a violation in some manner, but doesn't try to do so, then I think we would look upon that compromise with less favor than if the person or business made that attempt. I am assuming here, as noted above, that one cannot simply claim 
some sort of exculpation that would block demands requiring remediation or the reduction of the harmful aspects of the violation. ${ }^{38}$

What about Google? In Google's case, as in all other such cases, we must ask first whether there are ways in which they can avoid this compromise. This means they should try to act differently than they presently are. Perhaps, greater efforts or more creativity are required. Even the use of additional moral suasion and moral power to move the Chinese government to take or permit a different stance must be considered. In any case, there is an appropriate realm here within which moral activists may work to move Google and China to respect human rights.

However, assuming that such efforts fail and compromise of the sort Google has made is the most reasonable option, they must still seek to ameliorate the effects of the actions they are undertaking. As I have noted above, Google did, in fact, undertake several steps, when instituting this filter or censorship regime, to mitigate the effects of what they are doing. These included the following: (a) They have placed a notice on one's screen when they have blocked a webpage. ${ }^{39}$ (b) They have chosen not to start email accounts and blogs, so that they would not have private or personal information which the government could request. (c) And, they say they will monitor the situation and how it develops. This is, at least partial, compliance with a mitigation condition.

Are there other things that Google could (should) do to mitigate the compromise they have made? Among such actions, as others have also noted, would be the following:

- Reaffirm their belief in freedom of expression and that it is central to its own values.

- Work within the Chinese system to support the Chinese constitution and its guarantee of the freedom of speech and of publication. ${ }^{40} \mathrm{It}$ may be assumed that the senior Chinese leadership is not simply monolithic in its views regarding Internet censorship. Google should try to work with those more favorable to moderating the current censorship regime.

- Provide a list of terms for which they filter, and do this at all locations where they filter.

- Indicate that filtering is a temporary means of avoiding the violation of other important values, and that they are looking for ways to end it.

- Indicate that they are filtering at the behest of others (and name them), but not at their own choice.

- Provide circumventing information.

- Work with other Internet companies and stakeholders to develop a common code of conduct they would all commit to adhere to. ${ }^{41}$

These actions may be seen as shaping the form of the compromise Google is facing. Similarly, Sher attempts to articulate the form that those on either side of the abortion question might take in arriving at a compromise that both sides might accept (see Sher, 1981, p. 370). That is, the compromise Google would make would be to filter certain terms they believe absolutely necessary, while reaffirming their belief in the importance of freedom of expression.

In short, moral purity may not be possible in the world that most individuals and businesses face. Moral conflict may require moral compromise. However, this requires other moral efforts to mitigate and to reduce (if not end) that compromise. This is not to say that Google would be wrong to withdraw from China. However, morality does not demand this. This would be to take the part of the moral ideal or saint, rather than what is morally permitted. ${ }^{42}$

\section{Implications and conclusions}

Businesses face complex, difficult, and unavoidable ethical situations wherever they operate, but especially so in international contexts. The case of Google is an instructive example. Not only does Google encounter a dilemma in deciding whether or not to do business in China, but business ethics thereby faces a dilemma also. If business ethics holds to the importance of human rights and tells Google to go home, it risks being cast as impractical and unrealistic, though idealistic and pure. And if it permits Google to operate in China by filtering, it risks being cast as having been co-opted by business and indifferent to important ethical concerns. 
Google's own resolution of this situation proceeds by avoiding most of the important ethical issues. Those issues involve human rights and moral compromise. Though Sergey Brin has spoken of Google's compromise, the official Google justification for its operations as offered by Elliott Schrage to Congress makes no mention of either human rights or moral compromise. However, human rights have received a great deal of attention by business ethicists and, increasingly so, by business (see the Business Leaders Initiative on Human Rights). Moral compromise has received much less attention from either. This paper argues that, on certain occasions, moral compromise may be defensible. This is not intended to make moral life for businesses easier, but to recognize the moral context and the structure of the moral situations in which they operate.

In circumstances that fulfill what I (and others) have referred to as "conditions of compromise," a reasonable actor standard may morally approve actions that compromise important moral principles and values. I have argued that Google's situation regarding operating in China fulfills these conditions. That said, Google's decision to filter the Internet is only justified if it is based upon other values and followed by other (mitigating) actions. In short, this account argues that what Google did is morally permitted, so long as it is accompanied by these other actions that seek to mitigate and reverse what it is presently doing. The paper does not argue that what Google did was morally required.

Finally, this discussion reminds us that the broader issue of moral compromise has not been sufficiently examined by business ethicists. Instead, we are often instructed as to how we ought to view important moral issues, e.g., international bribery, but then told that when individual managers face such issues, there are no satisfactory solutions (see Donaldson and Dunfee, 1999, p. 230). At this point, managers are told that they should refer to the country's background institutions, that companies should make a point not only of speaking out against bribery, and cooperate in doing so with other companies (Donaldson and Dunfee, 1999, p. 230). However, we are told little more after this point. Similarly, De George has also spoken about the need to shift levels to resolve certain problems (see De George, 1993). These are excellent points. However, what does the individual manager or business do while that shift is taking place? In this conflicted, imperfect situation, they need to know what to do and why? Much of their actual life is spent there.

Such accounts leave the individual manager and business without any moral guidance. How should they act in an immoral and non-perfect world? More importantly, how should they act in a world without the appropriate support structures and moral behavior of governments? The framework offered in this article is an attempt to address this imperfect situation. ${ }^{43}$ Business ethicists need to spend more time addressing the role of moral individuals and businesses in imperfect and immoral situations. If they do so, they will have to consider the role of moral compromise with greater attention than they have. ${ }^{44}$

\section{Notes}

1 See the UN Universal Declaration of Human Rights, Article 19. See Amnesty International's statement "Amnesty International Blasts..." July 21, 2006.

2 "Google response to Amnesty International...," 2006, p. 1.

3 Ibid. Elliot Schrage, Google's VP for Global Communications and Public Affairs, refers to "Don't be evil" as Google's "mantra." In the Google Code of Conduct it is referred to as their "motto."

4. See Amnesty International's statement "Amnesty International Blasts..." July 21, 2006.

5 See the "Joint Investor Statement on Freedom of Expression and the Internet" (Reporters Without Borders, 2006b). This document argues that Internet companies have a particular responsibility in this domain to protect freedom of expression as a universal human right. Of course, given this situation of a company over a town, it might be argued that it has become their government and is no longer simply "private" but has become a "public" body.

6 Recall the example above of a private company that runs a town and, as such, would be a responsible party regarding its citizens' right to information.

7 This is not to say that they may not be engaged in forms of censorship that are morally questionable for other reasons than violating people's right to information. And, if such private organizations proclaim that they do not censor their services, then they wrong those who use them through their hypocrisy and the misrepresented services they provide.

8 Human Rights Watch comments that "the censored Google.cn...still enables the Chinese user to 
access substantially more information on sensitive political and religious subjects than its Chinese competitors" (Human Rights Watch, "Race to the Bottom," 2006, p. 5).

See UN Global Compact, n.d. The UN Global Compact was founded in July, 2000 at the United Nations. It offers businesses a framework by which to align their "operations and strategies with ten universally accepted principles."

10 Ibid.

11 The UN Global Compact distinguishes three kinds of complicity: direct, beneficial, and silent. Neither beneficial nor silent complicity are relevant here. The most relevant is direct complicity, but for reasons given in the text, this too seems better replaced by "obedient complicity."

12 The point here is morally (though not legally) similar, I believe, to Principle IV of the Nuremberg Principles that states: "The fact that a person acted pursuant to order of his Government or of a superior does not relieve him from responsibility under international law, provided a moral choice was in fact possible to him." (see "Principles of International Law...," 1950, p. 2).

13 An anonymous reviewer suggested this point.

14 Because some lawmakers in the US believe that Google and other Internet companies are wrongly filtering the Internet, they have proposed the Global Online Freedom Act of 2006 (Rep. Chris Smith). Part of this bill would prevent “...companies from hosting email servers or search engines within Internet-Restricting Countries, or establishing any kind of presence in such countries that would make it liable to political censorship..." (Smith, 2006).

15 It is not persuasive to deny Google's complicity by pointing out that Google offers a free service to Chinese Internet users. The question does not regard whether or not that service is paid for by its users, but the nature of that service. In this case, it is in compliance with the unjustified rules and laws of the Chinese government.

16 I don't consider here whether Google's participation in this filtering activity might be said to lend the Chinese government's actions some cover or legitimacy. Of course, Google could avoid this by refusing to filter the Internet in China. However, the competitive costs would be, supposedly, great in the long run.

Some argue that rather than lending the government legitimacy, Google's actions actually highlight the Chinese government's heavy-handed insecurity. I don't try to resolve this dispute here.

17 In fact, Google needs a theory of when censorship is morally justified. Only then will it know whether the requests it receives to filter the Internet are justified.
One part of that theory would be whether the government of a country requesting that filtering is legitimate, and whether that filtering is itself justified. Obviously, these involve complex issues, only the second one of which is (partially) discussed here.

18 Kuflik invokes the notion of judgments, "all things considered," in his essay (Kuflik, 1979). He then adds: "When an issue is in dispute there is more to be considered than the issue itself - for example, the importance of peace, the presumption against settling matters by force, the intrinsic good of participating in a process in which each side must hear the other side out and try to see matters from the other's point of view, the extent to which the matter does admit reasonable differences of opinion, the significance of a settlement in which each party feels assured of the other's respect for its own seriousness and sincerity in the matter" (Kuflik, 1979 , p. 51). In discussing Google's situation, other considerations than these arise, but Kuflik's comment suggests the breadth of considerations that fall under an "all things considered" judgment.

19 See Bernard Williams comment: "many people can recognize the thought that a certain course of action is, indeed, the best thing to do on the whole in the circumstances, but that doing it involves doing something wrong" (Williams, 1972, p. 93). See Walzer, 1973, p. 160.

20 This is the nature of compromise discussed, by and large, in the book Compromise in Ethics, Law, and Politics (Pennock and Chapman, 1979). Still, this is not to say that moral compromises might not have to take place here!

21 Of course, some, such as Benditt, may consider what Google has done, vis-a-vis the Chinese government as simply a case of capitulation or of appeasement, not of compromise (Benditt, 1979, p. 26). This occurs, he contends, when only one party alters its position. Since we don't know to what extent the Chinese government has altered its position by allowing Google to post an indication that filtered web pages have been removed in accordance with Chinese law (Parr, 2006, p. 86), it is not possible to speak to this sense of compromise in this case.

22 Rand comments: "There can be no compromise on moral principle" (Rand, 1964, p. 70; italics removed). "It is only in regard to concretes or particulars, implementing a mutually agreed basic principle, that one may compromise" (Rand, 1964, p. 68).

23 This objection must rest, seemingly, on the view that our moral principles don't conflict. Thus, for example, such a view is captured in Donaldson's "compatibility proviso," according to which our basic principles cannot conflict (cf. Donaldson, 1989, pp. 77-80). 
24 Donaldson defended such a view in his "Compatibility proviso" in The Ethics of International Business, cf. pp. 77-80. Shue, however, allows that rights may conflict, though he contends that while basic rights may require that we sacrifice non-basic rights, the reverse is not the case (cf. Basic Rights, p. 19; Donaldson, 1989, p. 78).

25 See Hampshire identifies "the doctrine of moral harmony" as the view that "a morally competent and clear-headed person has in principle the means to resolve all moral problems as they present themselves, and that he need not encounter irresoluble problems..." (Hampshire, 1983, p. 144).

In contrast, Hampshire claims that "...there must always be moral conflicts which cannot, given the nature of morality, be resolved by any constant and generally acknowledged method of reasoning. My claim is that morality has its sources in conflict, in the divided soul and between contrary claims, and that there is no rational path that leads from these conflicts to harmony and to an assured solution, and other normal and natural conclusion" (Hampshire, 1983, pp. 151-152).

26 This is compatible, I believe, with Benjamin's view. "I shall concentrate on moral compromise, by which I mean compromise in the standard sense as it applies to conflicts rooted in opposing ethical considerations" (Benjamin, 1990, p. 23). Cf. also Williams on life projects (Williams, 1985).

27 I draw these conditions from the work of Martin Benjamin, Gregory Kavka, and Ronald Green. Situations involving compromise must be special in that we do not want compromise of moral values to be the answer to every difficult situation. Martin Benjamin has argued that situations of compromise share four characteristics: complexity; uncertainty; continuing, cooperative relationships; and nondeferrable decisions (Benjamin, 1990, pp. 26-32, 75, 164). Though I believe this schema needs some modification, I draw on it to discuss moral compromise in the text and the case of Google. Benjamin refers to these conditions as providing "the motivation and the grounds for compromise solutions" (Benjamin, 1990, p. 26). I see them as setting the context in which the conflicts arise in which compromise is a live option.

28 Sher also invokes the notion of complexity in his account of moral compromise (Sher, 1981, p. 369).

29 This is not to say that Google has a right to exist in the way that a human being might be said to have a right to exist. If one business outcompetes another business and, thereby, puts it out of existence, it has done nothing wrong. If one person is better able to do certain things such that another person's life is threatened, they have done something wrong.
30 One might ask whether Google would have made the same decision prior to having gone "public"? I assume it would have.

31 Ying Ma claims that what Congress has in fact done is not that much different from what Google has done (Ma, 2006).

32 The vulnerability at stake here need not be one in which both parties must be both equally vulnerable as Kavka has argued. Kavka suggests, as a condition that justifies compromise, that "the parties in question must be equal enough that each is vulnerable to destruction by the others" (Kavka, 1983, p. 63). He is worried that one is so large and powerful that it is not really threatened (Kavka, 1983, p. 63). I do not believe that such a condition is part of the circumstances of moral compromise. Surely, if two parties are involved and one has extraordinary powers and cannot be threatened, then any compromise coming from its side is likely to be remote. However, this does not mean that compromise might still not be possible on behalf of both parties, and certainly that compromise in the sense I discuss may not be something the weaker of the two must undertake.

33 Benjamin argues that, in some circumstances, with Nazis, racists, sexists, or rapists, compromise should be rejected out of hand (Benjamin, 1990, p. 125). I would rather not identify people, however evil, as outside the bounds of compromise. Rather, I would identify actions or policies they undertake that are outside the bounds. Thus, on some occasions, it might be necessary to compromise with a Nazi, but not over the creation of a concentration camp.

34 Here, I draw on the work of Benjamin and Kavka.

35 Accordingly, certain values structure, guide, and help to assess the exercise of judgment in the circumstances of compromise (Benjamin, 1990, p. 121). Benjamin contends that the principal values are individual integrity, overall utility (including social utility), and equal respect (p. 123). We must ask whether a particular compromise affects the overall good. I offer a related, though somewhat different, account.

36 Though morality is often seen as pitted against non-moral, self-interested, customary, etc. factors, it is better to see it as part of how individuals develop flourishing lives and businesses become excellent enterprises. As such, morality is a complex institution that involves conflicting moral demands which are such that to follow one or the other might result in significant practical and prudential costs on a person or organization.

37 See Hobbes' comment that "no man is bound to...make himself a prey to others, and procure his own certain ruine" (cited by Kavka, 1983, p. 62). 
38 In some cases, regret or guilt may be appropriate if one cannot do anything to modify or reduce extremely harmful results of unavoidable moral compromises (see Walzer, 1973).

39 Without this, a person using the Internet may have the impression that his/her search is completely free, even though it is not. Tim Wu notes that the Chinese are attempting "...to make filtering a basic fact of the Web. And filtering a tool like a search engine has the benefit of subtlety, because to most people, searches will feel free even when they're not. How many of us can tell when something goes missing in a Google result"? (Wu, 2005, p. 1).

40 See Amnesty International, 2006, p. 24. See also "Freedom of Expression, Speech and the Press," Congressional Executive Commission on China, 2006.

41 Human Rights Watch refers to the development of such a code (Human Rights Watch, 2006, p. 4). More recently, there have been news accounts of ongoing efforts to create such a code.

42 It might be objected that an important, and unacceptable, implication of the preceding ethical framework is that it would permit Google (and other businesses) to bribe Chinese officials. In fact, wouldn't this framework permit people and businesses that are under considerable pressure to act in immoral ways and thereby excuse them?

There are three parts to my answer. First, the framework offered in this article does not mean that what a business would do in such cases is right in itself. As is the case with the filtering Google is doing in China, bribery is wrong. It should be avoided. There remains moral pressure on any person or business to avoid such actions. Second, the preceding recognizes, what we know to be the case, that when people and organizations are in difficult situations, this may justifiably affect what they do. The danger is that they come to accept what they do as the status quo. The view I offer does not offer them that escape. Finally, in the case of bribery, there are legal and moral authorities who can, and are, effectively attacking this issue. As such, it would seem unjustified to compromise on that moral issue.

43 If, indeed, these other groups and governments seek to have businesses operate on strict moral requirements without being prepared to foster the conditions in which action on those requirements is possible or reasonable, then those making these demands are themselves being hypocritical and are part of the problem.

44 This article has benefited a great deal from the helpful comments of two anonymous reviewers. I thank them for their comments and suggestions.

\section{References}

Amnesty International: 2006, Undermining Freedom of Expression in China (Amnesty International UK, London).

Anonymous: 2006a, 'The Party, the People and the Power of Cyber-talk', The Economist 379, 27-30.

Anonymous: 2006b, 'Amnesty International Blasts Yahoo, Microsoft, Google for China Dealings’, www.foxnews. com. July 21, 2006.

Anonymous: 2006c, 'Internet Censorship in the People's Republic of China', http://en.wikipedia.org/wiki/ Internet_censorship_in_China. Downloaded September 22, 2006 .

Barnett, R.: 2005, 'How Business Ethics Failed Corporate America', www.projectmagazine.com/v3i7/ethicsv3i7. html. November 3, 2005.

Benditt, T. M.: 1979, 'Compromising Interests and Principles', in J. R. Pennock and J. W. Chapman (eds.), Compromise in Ethics, Law and Politics, NOMOS XXI (New York University Press, New York), pp. 26-37.

Benjamin, M.: 1990, Splitting the Difference: Compromise and Integrity in Ethics and Politics (University of Kansas Press, Lawrence, KS).

Bridis, T.: 2006, 'Brin Says Google Compromised Principles', http://www.mercurynews.com/mld/mercury news/news/local/states/california/northern_california/ 14755205.htm. Downloaded September 21, 2006.

Bowden, T. A.: 1999. 'Blacklists are not Censorship', http://www.aynrand.org/site/News2?page=News Article\&id=5242\&news_iv_ctrl=1021.

Business Leaders Initiative on Human Rights: n.d., 'A Guide for Integrating Human Rights into Business Management', http://www.blihr.org/Pdfs/GIHRBM. pdf. Accessed September 22, 2006.

Business and Human Rights Resource Center: 2006, 'Google Response Regarding Amnesty International Action on Censorship in China', www.businesshumanrights.org. Accessed February 25, 2008.

CNN: 2006, 'Web Firms Criticized over China', http:// edition.cnn.com/2006/TECH/internet/07/20/china. internet.ap/. July 20, 2006.

Congressional Executive Commission: 2006, 'Freedom of Expression, Speech and the Press', http://www.cecc. gov/pages/virtualAcad/exp/. Accessed May 8, 2008.

De George, R.: 1991, 'Green and Everybody's Doing It', Business Ethics Quarterly 1(1), 95-100.

De George, R. T.: 1993, Competing with Integrity in International Business (Oxford University Press, New York).

De George, R. T.: 1999, Business Ethics (Prentice-Hall, Saddle River, NJ). 
Delaney, K. J.: 2006, 'Google to Launch Service in China', Wall Street Journal, January 25, p. B2.

Donaldson, T.: 1989, The Ethics of International Business (Oxford University Press, New York).

Donaldson, T. and T. W. Dunfee: 1999, Ties that Bind (Harvard University Press, Boston).

Green, R. M.: 1991, 'When is "Everyone's Doing It" a Moral Justification?', Business Ethics Quarterly 1(1), 75-93.

Halfon, M. S.: 1989, Integrity: A Philosophical Inquiry (Temple University Press, Philadelphia).

Hampshire, S.: 1983, Morality and Conflict (Harvard University Press, Cambridge, MA).

Human Rights Watch: 2006, 'Race to the Bottom', Vol. 18, No. 8(C) (August), http://www.hrw.org/reports/ 2006/china0806/china0806webwcover.pdf. Accessed May 8, 2008.

Internet Society of China: 2002, 'Public Pledge of SelfRegulation and Professional Ethics for China Internet Industry', www.isc.org.cn/200020417/ca102762.htm. Accessed August 14, 2006.

Joint NGO Letter in Response to Interim Report: 2006, www.fidh.org/IMG/pdf/Joint_NGO_Response_to_ Interim_Report.pdf. Accessed May 8, 2008.

Kavka, G. S.: 1983, 'When Two 'Wrongs' Make a Right: An Essay on Business Ethics', Journal of Business Ethics 2, 61-66.

Khan, I.: 2006, Amnesty International Letter to John Ruggie (April 27, 2006).

Kirby, C.: 2005, 'Chinese Internet vs. Free Speech. Hard Choices for U.S. Tech Giants', San Francisco Chronicle, www.sfgate.com/cgi-bin/artilce.cgi?file=/ c/a/2005/09/18/MNGDUEPNLA1.DTL. Downloaded August 28, 2006.

Kirchgaessner, S.: 2006, 'Yahoo Wants United Front on China Censorship', FT.com (February 13, 2006. http://news.ft.com/cms/s/d14aef8c-9c0d-11da-8baa$0000779 \mathrm{e} 234 \mathrm{o}, \mathrm{s} 01=1 . \mathrm{html}$.

Kuflik, A.: 1979, 'Morality and Compromise', in J. R. Pennock and J. W. Chapman (eds.), Compromise in Ethics, Law and Politics, NOMOS XXI (New York University Press, New York), pp. 38-65.

Leisinger, K.: 2006, 'On Corporate Responsibility for Human Rights', Basel (April).

Ma, Y.: 2006, 'Google "Congress and Hypocrisy", http:// www.cbsnews.com/stories/2006/02/02/opinion/main 1272920.shtml. Accessed February 25, 2008.

Paine, L. S.: 1994, 'Managing for Organizational Integrity', Harvard Business Review March-April, 106-117.

Pan, P. P.: 2006, 'The Click that Broke a Government's Grip', Washington Post February 19, p. A01.

Parr, M.: 2006, 'Google's China Problem and China's Google Problem', New York Times Magazine (April 23, 2006), pp. 64-71, 86, 154, 155, 156.
Pennock, J. R. and J. W. Chapman (eds.): 1979, Compromise in Ethics, Law and Politics, NOMOS XXI (New York University Press, New York).

Principles of International Law Recognized in the Charter of the Nürnberg Tribunal and in the Judgment of the Tribunal: 1950, http://untreaty.un.org/ ilc/texts/instruments/english/draft\%20articles/7_1_ 1950.pdf. Accessed April 13, 2008.

Rand, A.: 1964, The Virtue of Selfishness (The New American Library, Inc, New York).

Rasch, M.: 2005, 'Human Rights and Wrongs Online', www.securityfocus.com/print/columnists/392.

Reporters Without Borders: 2006a, 'Google Launches Censored Version of Its Search-Engine', www.rsf.org/ print.php3?id_article=16262. Downloaded January 25, 2006.

Reporters Without Borders: 2006b, 'Joint Investor Statement on Freedom of Expression and the Internet', http:// www.rsf.org/fonds-investissement-en.php3. Accessed February 25, 2008.

Rudolf, G.: 2003, ;Censorship of the Internet', www.vho. org/tr/2003/2/Rudolf220-22.html (July 18, 2006).

Santoro, M. A.: 1998, 'Engagement with Integrity: What We Should Expect Multinational Firms to do About Human Rights in China', Business \& the Contemporary World $\mathbf{X}(1), 25-54$.

Schrage, E.: 2002, 'Why CSR is a Corporate Governance Challenge', Ethical Performance (October 1, 2002).

Schrage, E.: 2006, 'Testimony of Google Inc. Before the Subcommittee on Asia and the Pacific, and the Subcommittee on Africa, Global Human Rights, and International Operations', http://googleblog.blogspot. com/2006/02/testimony-internet-in-china.html. Accessed February 15, 2006 (11 pages).

Sher, G.: 1981, 'Subsidized Abortion: Moral Rights and Moral Compromise', Philosophy \& Public Affairs 10(4), 361-372.

Solely, L.: 2002, Censorship, Inc (Monthly Review Press, New York).

Smith, C.: 2006, 'Internet Should not Become Tool of Repression, Lawmaker Says', http://usinfo.state.gov/ dhr/Archive/2006/Mar/21-178338.html. Accessed February 25, 2008.

Thompson, C.: 2006, 'Google's China Problem (and China's Google Problem)', The New York Times (April 23).

UN Global Compact: n.d., 'The Ten Principles', http:// www.unglobalcompact.org/AboutTheGC/TheTen Principles/index.html. Accessed May 8, 2008.

UN Global Compact/Office of the United Nations High Commissioner for Human Rights (UNHCHR): 2004, Embedding Human Rights in Business Practice (New York). 
Vogel, D.: 2006, The Market for Virtue (The Brookings Institution Press, Washington, DC).

Walzer, M.: 1973, 'Political Action: The Problem of Dirty Hands', Philosophy \& Public Affairs 2(2), 160-180.

Williams, B.: 1972, Morality: An Introduction to Ethics (Harper and Row, New York).

Williams, B.: 1985, Ethics and the Limits of Philosophy (Harvard University Press, Cambridge, MA).
Wu, T.: 2005, 'The Filtered Future', http://www.slate. com/id/2122270. Accessed February 25, 2008.

Washington, DC 20057, U.S.A. E-mail:brenkg@georgetown.edu 